\title{
結核菌に対する光ギンテックの抗菌効果
}

石田慎一郎 ${ }^{* 1}$, 柳原和夫*1, 川延保隆 ${ }^{* 1}$,

菅原 勇 $^{* 2}$, 大友幸二 ${ }^{* 2}$, 華 樹成 ${ }^{* 2}$

\section{Antibacterial Function of HIKARI GIN-Tech on Mycobacterium Tuberculosis}

\author{
Shinichiro Ishida, Kazuo Yanagihara, Yasutaka Kawanobe, \\ Isamu Sugawara, Kouji Otomo, and Hua Shu Cheng
}

\section{Synopsis}

HIKARI GIN-Tech is a photocatalyst of anatase $\mathrm{TiO}_{2}$ powders, $7 \mathrm{~nm}$ in diameter, covered with satellites of extremely fine particles of silver. The synergistic reaction of $\mathrm{TiO}_{2}$ and $\mathrm{Ag}$ gives it an unrivaled powerful antibacterial function effective against a wide variety of pathogenic and resistant bacteria spreading in clinics. The laboratory test proved it is also effectual against tuberculosis bacteria. The spray with HIKARI GIN-Tech suspending in alcohol demonstrated the same function as powders themselves. The HIKARI GIN-Tech application products are under field tests in clinics with promising results.

\section{1 ・はじめに}

1882 年コッホによって発見された結核菌は, 人から 人へ伝染する飛沫感染症の代表的な菌であり，1950 年ま では国内における死亡率第 1 位の病原菌であった．弚の 後, 医療技術の目覚しい進歩によって結核罹患率 (新発生 患者数) は年々減少し，結核症はすでに克服された過去の 病気になったと言っても過言ではない．しかし近年，結核 菌による集団感染が世界的に急増している.特にほとんど の抗生物質が効かない多斉耐性菌が出現し，この菌による 肺結核症は難治性のため深刻な問題となっている．WHO は今後数年の間に結核症が世界の成人死因の第 1 位になる 可能性があると示唆しており, 国内でも 1997 年 , 43 年ぶ゙り に罹患率が増加に転じ，厚生省は結核緊急事態を宣言した。

このような薬剂而性菌に対し有効な抗菌剂として, 光触 媒が注目されている.フリーラジカル反応による抗菌機構 のため，解毒作用や耐性菌を作らないなどの大きな特徵が
あり，医療分野においての応用事例も少しずつ見受けられ るようになった 。

光触媒粉末に微細な銀を点在させた光ギンテックは, 光 触媒と銀の相乗作用で多種の菌に対し非常に強力な抗菌 効果を示すため, 院内感染対策の一助として病院から期待 されている.乥の一環として結核菌に対する抗菌効果を他 社に先駆けて検討したので報告する．

\section{2 . 光ギンテックの抗菌性能}

光ギンテックとは, 光触媒性を有するナノサイズのアナ ターセ型酸化チタン粉末の表面に, メタル銀の微粒子を担 持させた構造の微粉末である.污のモデルをFig.1に示す． 銀微粒子を担持させることで光触媒と銀が相乗的に働き， また超微粉末のため比表面積が大きく $\left(300 \mathrm{~m}^{2} / \mathrm{g}\right.$ 程度) 接 触効率が高いことも相乗して，優れた抗菌効果を示す．

入院患者の膿，尿や院内環境から臨床菌を採取し，二れ を試験菌として最小発育阻止濃度 (MIC) を測定した結果 
をTable 1 に示す．また，日和見感染で問題視されている 真菌に対しても臨床から採取し MIC を測定した . 兴の結 果をTable 2 に示す . 院内感染症の原因菌としてもっとも 注目されるメチシリン薬剤に耐性を示す黄色ブドウ球菌 $\ulcorner M R S A\lrcorner$, 感染すると皮膚，口腔，消化器官など全身に病 巣をつくる真菌「カンジダ」など, 光ギンテックはいずれ の菌に対しても強い抗菌性を示し，臨床における比較的生 命力の強い病原菌に対し有効な抗菌剂であることを確認 している。

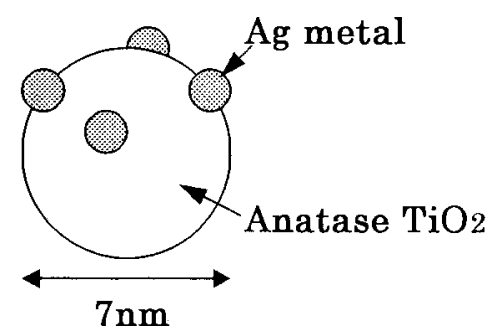

Fig.1. Basic model of "HIKARI GIN-Tech" particle.

Table 1. MIC measurement result to clinical bacterium.

\begin{tabular}{ll|c}
\hline \multicolumn{2}{c|}{ Germs gathered from clinical } & $\mathrm{MIC}(\mu \mathrm{g} / \mathrm{ml})$ \\
\hline M.R.S.aureus & MRSA & 200 \\
\hline P.aeruginosa & 緑膿菌 & 200 \\
\hline P.putida & プチダ菌 & 100 \\
\hline P.cepatia & セパシア菌 & 200 \\
\hline S.marcescens & セラチア菌 & 200 \\
\hline E.coli & 大腸菌 & 100 \\
\hline S.typhimurium & サルモネラ菌 & 100 \\
\hline \multicolumn{2}{c|}{}
\end{tabular}

Table 2. MIC measurement result to clinical fungus.

\begin{tabular}{l|l|c}
\hline \multicolumn{2}{c|}{ Germs gathered from clinical } & $\mathrm{MIC}(\mu \mathrm{g} / \mathrm{ml})$ \\
\hline C.albicans & カンジダ & $<50$ \\
\hline A.fumigatus & アスペルギルス・フミガートゥス & 100 \\
\hline A.flavus & アスペルギルス・フラバス & 100 \\
\hline A.niger & アスペルギルス・ニガー & 50 \\
\hline
\end{tabular}

\section{3 . 結核菌に対する抗菌効果}

\section{1 試験方法}

結核菌に対する光ギンテックの抗菌効果をFig.2 に示し た試験方法て調査した .ここで, Fig.3 の市販光ギンテッ クスプレーは,形状が複雑なものや多樣な場所へ簡易に抗 菌コートを可能にした製品である .关の溶媒にはアルコー ルを使用しており，今回の試験においてアルコールの影響 をみるため, 蒸留水に光ギンテックを加えた水性光ギン テックスプレーも準備した .

試験は M.tuberculosis H37Rv，BCG Pasteur , M.avium の

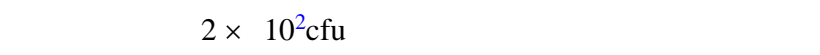
性コントロール, 市販光ギンテックスプレー (光ギンテッ ク+アルコール)，水性光ギンテックスプレー(光ギンテッ ク+蒸留水) の 3 群で, 噴霧時間を $1,3,5,10$ 秒で行 い, 噴霧後 3 週間培養して出現したコロニー形成単位 (cfu, colony forming unit) をカウントして光ギンテックの抗菌効 果を評価した。またDNA を抽出し，光ギンテックによる DNAへの影響をみた 。

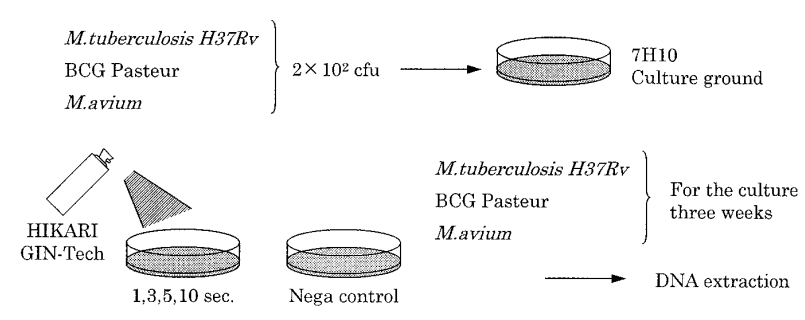

Fig.2. Method of examining antibacterial effect to Tuberculosis bacterium.

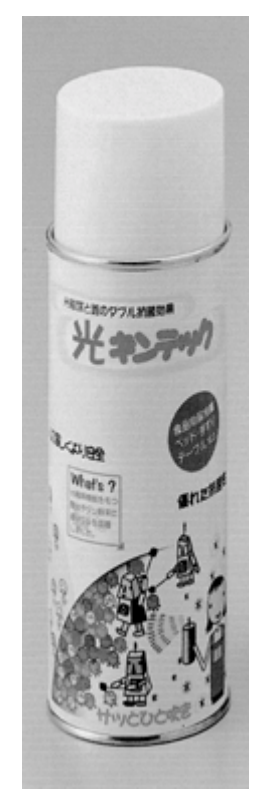

Fig.3. HIKARI GIN-Tech antibacterial spray.

\section{2 抗菌効果}

M.tuberculosis H37Rv の試験結果を Fig.4に , M.avium の 試験結果を Fig.5 に示す .

M.tuberculosis H37Rv を接種した培地に対し光ギンテッ クスプレーを $1,3,5,10$ 秒噴霧し，3 週間培養して出現 したコロニー数は，光れ午れ $186 ， 23 ， 0 ， 0 \mathrm{cfu}$ で, 噴霧 してない陰性コントロールでは，弚れ光れ $210,186,195$ ， $196 \mathrm{cfu}$ であった .陰性コントロールに対し，噴霧 1 秒にお いては出現数がわずかに下回り, 3 秒では $23 \mathrm{cfu}$ と出現数 が大きく減少し , 5,10 秒ではコロニーは出現していない . 
水性光ギンテックスプレーを噴霧したときのコロニー出 現数は，弚れ羿れ $170,44,6,0 \mathrm{cfu}$ であった . 5 秒では $6 \mathrm{cfu}$ となり，光ギンテックスプレーよりも効果がやや弱 かったが，10 秒ではコロニーがみられなかった .

BCG Pasteur , M.avium でもほぼ同樣の結果であったが， なかでも近年増加する MAC 症の原因菌である M.avium に 対しては,他の結核菌よりも3 秒でのコロニー出現数がや や少なく，高い抗菌効果を示した .

以上の結果より,光ギンテックは結核菌に対し大きな抗 菌作用をもつことが判明した .なお, 光ギンテックスプ レーの方か強い抗菌効果を示したのは,スプレーに含まれ るアルコールが光ギンテックと相乗して働いたと考えら れる.また本試験は，培地上に光ギンテックを点在させて いく条件であり, 菌との接触効率が抗菌効果と関係してく る.スプレー噴霧時間が長くなればとれだけ光ギンテック の点在率が高くなり，抗菌効果がより確実になることがこ の実験から明らかである .

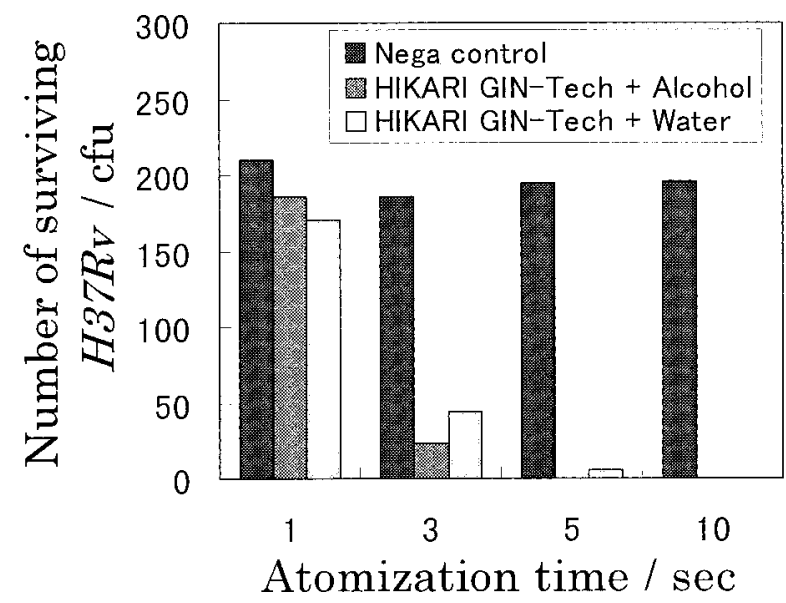

Fig.4. Antibacterial effect on M.tuberculosis H37Rv.

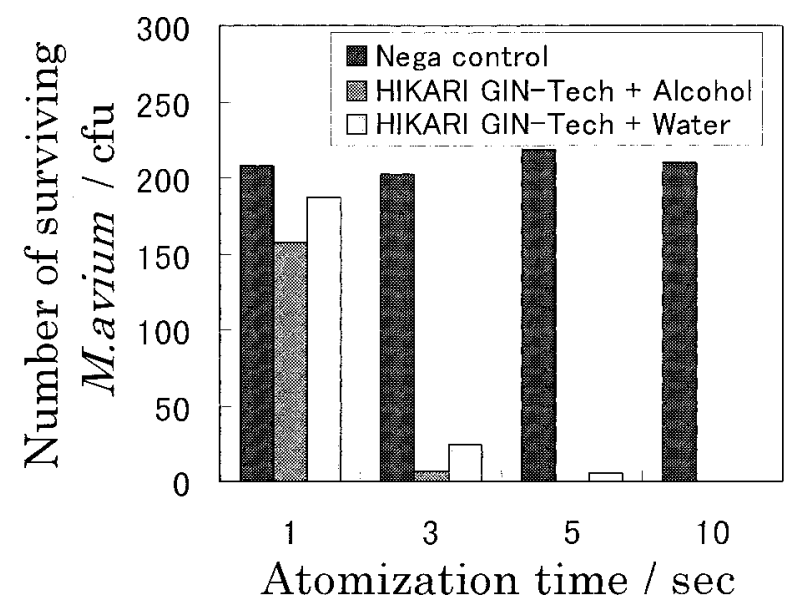

Fig.5. Antibacterial effect on M.avium.

\section{3 抗菌メカニズム}

DNA の損傷状況を測定し, 光ギンテックの結核菌に対 する抗菌メカニズムを考察した . M.tuberculosis H37Rv に 対し , $0.9 \% \mathrm{NaCl}, 70 \%$ アルコール , 水性光ギンテックスプ レー, 市販光ギンテックスプレーを作用させ , 1 週間後に DNA を抽出し電気泳動した結果をFig.6に示す. $23 \mathrm{Kbp}$ に あるバンドは正常な DNA 鎖長を表し,DNA 鎖が破壊され ていると,光の断片を表すバンドが短い部位に現れる.試 験結果を観察すると 4 種類とも長部位にバンドがみられ， DNA を損傷した形跡はない. 光ギンテックの抗菌機構は DNA に作用するのではなく，細胞壁成分などに作用する ものと推察する .

\section{Kbp}

23

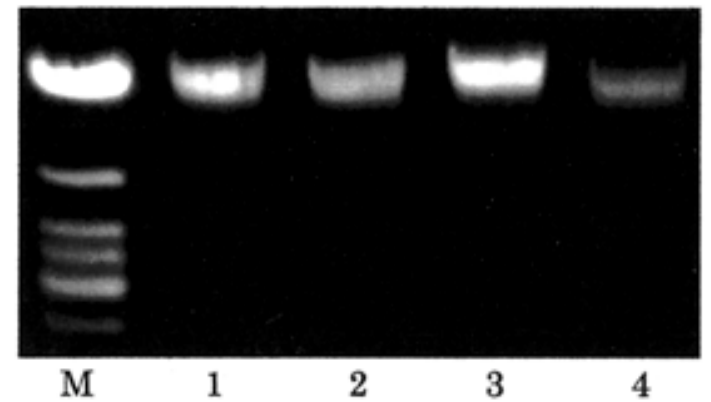

$1: 0.9 \% \mathrm{NaCl}$

2:70\% Alcohol

3:HIKARI GIN-Tech

+ Water

\section{4:HIKARI GIN-Tech} + Alcohol

Fig.6. Influence on DNA of M.tuberculosis H37Rv.

\section{4 . 製品への応用}

結核菌は患者がくしゃみ,会話することなどにより，菌 を含む飛沫が飛び散る.飛沫から水分か蒸発し, 微細な飛 沫核となった結核菌は長時間にわたり室内に浮遊し，弚の 空気を呼吸する人はみな感染の危険にさらされる.結核菌 に限らず,MRSA などの細菌やカンジダなどの真菌，イン フルエンザウイルスなどさまざまな菌が浮遊し飛沫感染 する危険がある .

今回得た試験結果から，抗菌効果を充分に満足できる光 ギンテック量を活性炭に吹き付けた光ギンテックフィル タを開発した .このフィルタは, 浮遊菌を活性炭で素早く 捕らえ光ギンテックで抗菌除去する機能をもつ.关の性能 を確認するため, Fig.7 に示す試験方法で浮遊菌低減効果 を測定した．すなわち人工的に浮遊させた大腸菌をフィル タに通過させ捕集率と抗菌効果を測定した.発生させた浮 遊大腸菌 $252 \mathrm{cfu}$ は $95 \%$ 捕集され，光の高い接触効率から 
60 分後には捕集した菌すべてが死滅しており，優れた抗 菌効果が示された .

また ,このフィルタは光ギンテックの光触媒作用により 悪臭などの臭気も同樣に分解除去できる.Fig.8 は煙草の 成分であるアセトアルデヒドに対する分解除去効果を測 定したもので 銀を担持した光ギンテックは市場で使用さ れる光触媒単体よりも分解能力が $40 \%$ も高い.

感染経路の対策として飛沫感染が起こりうる病棟や待 合室など，また院内特有の臭気対策として，この光ギン テックフィルタを応用した抗菌・防臭パネル (Fig.9) や ガス分解機 (Fig.10) を製品化しており，院内環境改善の 一助として期待されている .

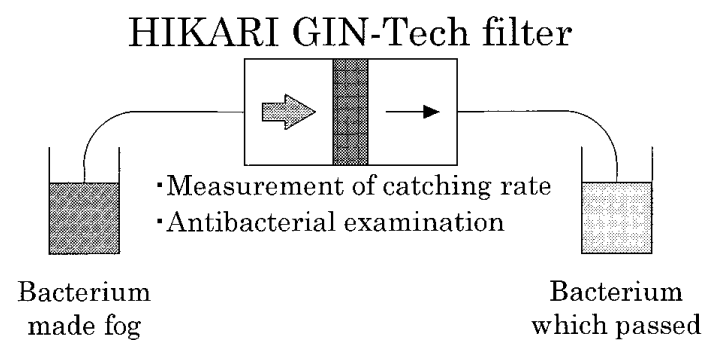

Fig.7. Measurement of HIKARI GIN-Tech filter performance to floating bacterium.

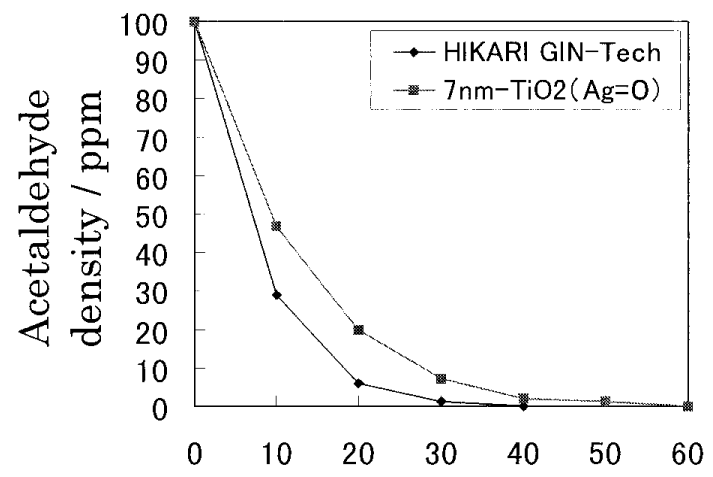

Deodorization times / min.

Fig.8. Measurement of photocatalyst performance.

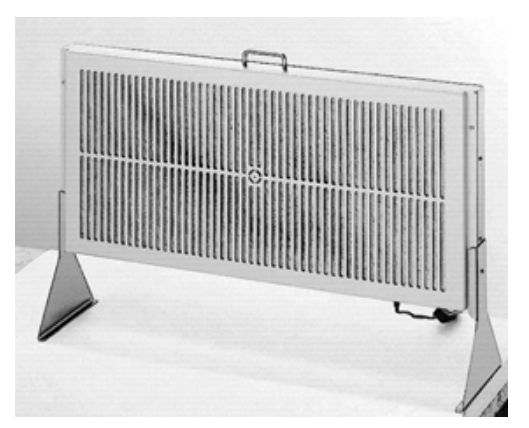

Fig.9. Antibacterial and deodorization panel.

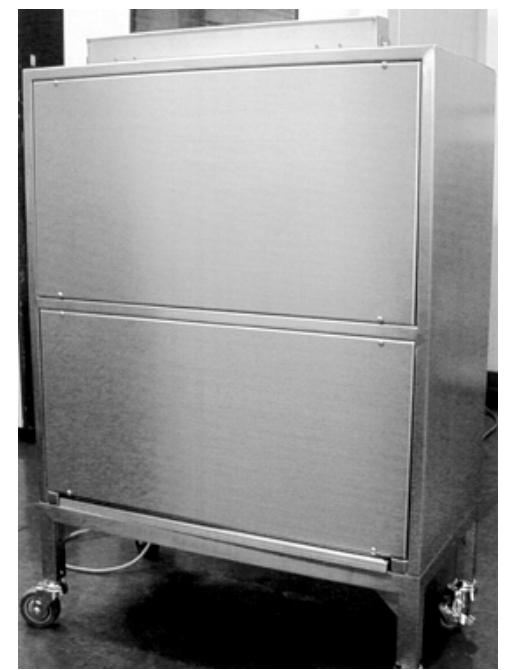

Fig.10. Air purifier with HIKARI GIN-Tech deodorization system.

$$
\text { 5.まとめ }
$$

結核菌に対する光ギンテックの抗菌効果をスプレー噴 霧することで評価した．弚こで，以下の結果を得た．

(1) 光ギンテックは結核菌に対し有効な抗菌効果を示す.

(2) 光ギンテックの抗菌作用は菌体の DNA に損傷がみら れないことから，細胞壁成分に作用するものと考えら れる．

本試験結果から，光ギンテックを応用した独自の抗菌・ 防臭製品を開発し，現在，高いレベルの効果が要求される 院内環境にて臨床試験を進めている．

\section{謝辞}

臨床分離菌に対する MIC 試験をしていたただきました 名城大学 薬学部微生物学研究室 二改俊章氏, 小森由美子 氏，浮遊菌に対する性能測定をしていただきました大同病 院 環境測定センター 新谷良英氏, 折登宏之氏に深く感謝 いたします．

\section{(文 献)}

1)華樹成，大友幸二, 菅原勇, 柳原和夫，石田慎一郎:第47回 日本臨床病理学会, (2000)。

2)例えば 青木正和:日本医師会杂倠誌,121(1999) 339.

3)西村民雄: 誰でもわかる抗菌の基礎知識，(1999)，(蛛テク ノシステム

4)坂上吉一: 消毒·殺菌·抗菌バイブル ,(1998) , 大泉書店 . 